\title{
Rozdíly mezi pravdivou a lživou online textovou komunikací
}

\section{Differences Between True and Deceptive Online Text Communication}

\author{
Václav Linkov, Pavel Šmerk
}

\begin{abstract}
This article presents and discusses the results of a linguistic analysis of the differences between non-deceptive and deceptive messages used within computer-mediated communication. The primary method for this study was an experiment involving 28 participants who were asked to communicate with a partner using Windows Live Messenger, and then instructed to have a chat with another partner during which they were told to lie about themselves. Linguistic analysis revealed a greater number of numerals and words in the genitive case, a greater average message length, and a higher ratio of nouns + verbs to adjectives + adverbs in communication that was not intended to deceive the communication partner. In deceptive communication, however, a larger number of first degree words, adverbs, sentences and question marks were found. The analysis was also controlled for gender, and it was discovered that compared to women, men more often tended to change the characteristics of their language when lying. Women, on the other hand, changed their communication strategies for lying by asking questions more often and writing shorter messages.
\end{abstract}

KEYWORDS Computer-mediated communication, cues, deception detection, linguistic analysis

Lhaní (či klamání, v článku tyto pojmy budeme brát jako synonyma) je běžnou součástí komunikace. Otázka, jak lze lháře odhalit, byla zkoumána již odedávna. Ve středověku se lhaní zjišt’ovalo přiložením žhavého železa na kůži, kdy se věřilo, že pravdomluvný člověk nemůže být popálen, v 19. století frenologové rozeznávali lháře podle tvaru lebky v okolí uší, grafologové odhalovali lháře analýzou jejich písma. Ve dvacátém století se postupně vyvinuly sofistikovanější techniky, jako např. polygraf - detektor lži (Ford 2006).

Vzhledem k anonymitě, kterou poskytuje prostředí internetu, je i zde lhaní častým jevem. Na chatech mohou lidé vystupovat pod falešnými identitami, hrát si zde na osoby opačného

Sociální studia. Fakulta sociálních studií Masarykovy univerzity, 2/2009. S. 73-95. ISSN 1214-813X. Studie vznikla s podporou výzkumného záměru „Psychologické a sociální charakteristiky dětí, mládeže a rodiny, vývoj osobnosti v době proměn moderní společnosti““ (MSM0021622406), který probíhá na Fakultě sociálních studií Masarykovy univerzity. Výzkum byl dále podporován z prostředků Centra základního výzkumu LC536 Ministerstva školství ČR a projektů 1ET200610406 Akademie věd ČR a GA407/07/0679 Grantové agentury ČR. 
pohlaví, dělat ze sebe někoho, kým nejsou. $\mathrm{K}$ tomu, že někdy na internetu lhali, se přiznalo 30 \% z 250 respondentů Caspia a Gorskyho (2006). Podle jejich výsledků lžou častěji mladší, zkušenější a častější uživatelé internetu. Dělají to hlavně proto, že se chtějí pobavit nebo chránit svoje soukromí. Pouze $15 \%$ z jejich respondentů při lhaní online cítí stres, pouze $30 \%$ vzrušení nebo napětí, 80 \% se při lhaní baví (Caspi, Gorsky 2006). Co se týče frekvence lhaní na internetu v porovnání s offline komunikací, Hancock, Thom-Santelli a Ritchie (2004) při zkoumání deníků svých respondentů zjistili, že během synchronní internetové komunikace přes Instant Messenger (IM) se lže zhruba stejně často jako při komunikaci tváří v tvář. Lidé jsou přitom proti možnému lhaní ne vždy dostatečně imunní: Při komunikaci na chatech neberou v úvahu, že mohou být obelháváni, a domnívají se, že dokáží lháře odhalit (Koubalíková a Šmahel 2008). V některých př́ípadech (např. pedofilů lákajících pod dětskou identitou skutečné děti na schůzku) tak lhaní na internetu může být nebezpečné. Proto se vyplatí věnovat se zkoumání toho, jak lze lhaní při online komunikaci poznat.

V tomto článku se nejprve budeme zabývat tím, co to lhaní je. Dále popíšeme, za jakých podmínek lze lhaní nejlépe odhalit a jací lidé jsou v jeho detekci nejlepší. Potom se budeme zabývat charakteristikami lživé komunikace, kterými ji lze odlišit od komunikace pravdivé. Nakonec představíme dosavadní zjištění o charakteristikách lhaní na internetu. $\mathrm{V}$ druhé části článku uvedeme výsledky našeho vlastního výzkumu. V jeho rámci jsme si položili otázku, zda lze v češtině podobně jako v angličtině najít automaticky analyzovatelné jazykové charakteristiky, kterými se od sebe odlišují pravdivá a lživá komunikace. Nechali jsme proto naše respondenty nejprve komunikovat s druhým člověkem po internetu, a poté je nechali jinému člověku lhát. Obě konverzace jsme porovnali s použitím nástrojů pro automatickou analýzu českého textu a zjištovali, zda se konverzace v některých námi sledovaných charakteristikách liší.

\section{Lhaní}

„Minimální“ definici lhaní si můžeme vypůjčit od Hymana (1989): „Organismus S emituje signál, organismus R jej zaregistruje a věrí, že signál znamená, že X je pravda. Ve skutečnosti ale $\mathrm{X}$ pravda není.“ Toto lhaní nemusí být vědomé a může být způsobeno např. evolucí vzniklými mechanismy. Pro běžné chápání lhaní u lidí, kdy je bereme jako vědomou činnost, je lepší definice DePaulo, Lindsaye, Malonea, Muhlenbruck, Charlton a Coopera (2003), kteří definují lhaní jako „promyšlený pokus o oklamání druhých“. Lživá komunikace tedy není v jejich pojetí taková, kdy je klamající sám „oklamán“, čili myslí si, že to, co říká, je pravda. Ne všechny lži mají přitom za účel někoho poškodit. Mnoho pronesených lží má pouze „společenský“ charakter (,dobře vypadáte“) či slouží k tomu, aby „,hář“ lépe zapůsobil na druhé.

U většiny lidí se projevuje tzv. „truth bias“ (Newman, Pennebaker, Berry, Richards 2003) - výchozí předpoklad, že druzí lidé mluví pravdu. Mají-li se tedy rozhodnout, zda daný člověk lže, či mluví pravdu, často chybně pokládají lež za pravdu. Opačná tendence - tzv. „,investigator bias“" (Meissner, Kassin 2002) - se projevuje u odborníků, kteří se ve své praxi často setkávají se lhaním (policistů, psychiatrů apod.). Ti zase často mylně pokládají pravdu za lež. 
Bond a DePaulo (2006) ve své přehledové studii zkoumali úspěšnost detekce lhaní ve 206 publikovaných výzkumech. Měli-li se respondenti z jimi sledovaných studií rozhodnout, zda je sdělení pravdivé či lživé, určili $61 \%$ skutečně pravdivých zpráv jako pravdivé. U zpráv, které byly ve skutečnosti lživé, správně uhádli lživost pouze 48 \%. Proto také, pokud respondent ze sledovaných studií určil, že je zpráva pravdivá, byla pravděpodobnost, že je skutečně pravdivá, 54,1 \%. Naopak u zprávy považované za lživou byla pravděpodobnost 55,8 \%, že je skutečně lživá. Ze studie Bonda a De Paulo (2006) tak vyplývá, že celková přesnost správného určení pravdivosti či lživosti sdělení se u lidí pohybuje pouze mírně nad 50\% hranicí čisté náhody.

\section{Kdo a kdy dokáže Ihaní odhalit}

Ohledně lidské detekce lhaní je třeba nejprve uvést jeden skeptický výsledek: Bond a DePaulo (2008) metaanalýzou 140 studií zjistili, že rozdíly ve schopnosti jednotlivých lidí rozhodovat mezi pravdou a lží jsou malé. Větší rozptyl je v míře, jakým směrem lidé dělají chyby: zda mylně považují pravdu za lež či naopak (tedy zda aplikují „truth bias“ vs. „,investigator bias“"). Protože ve svém dřívějším článku Bond a DePaulo (2006) zjistili malou průměrnou schopnost lidí odhalit lež, zjištěný malý rozptyl vede k závěru, že téměř všichni lidé jsou špatní v detekci lhaní.

Nyní shrneme, co bylo zjištěno o tom, ve kterých situacích bývá lhaní snadněji detekováno, jakými způsoby, u kterých lidí a kteří lidé jsou lepší v jeho detekci.

Médium. Úspěšnost detekce závisí na komunikačním médiu. Bond a DePaulo (2006) uvádí, že lež jde při sledování pouhého obrazu mluvícího při vypnutém zvuku odhalit hưře, než máme-li k dispozici samotný text nebo audiozáznam jeho řeči. Dle jejich názoru je to způsobeno silným vizuální stereotypem toho, jak má vypadat lhár̆, který brání správné detekci. Při sledování videozáznamu jsou lidé méně skeptičtí než při čtení textu, může se tak více projevit „truth bias“ (Strömwall, Granhag 2003).

Motivace. Lži jsou při běžné (audiovizuální) komunikaci lépe detekovatelné, pokud je jejich zdroj více motivován (Bond, DePaulo 2006; Forrest, Feldman 2000) a př́jemce méně motivován (Forrest, Feldman 2000). DePaulo, Lanier a Davis (1983) zjistili, že je-li k dispozici pouze audiozáznam, jsou lži motivovaných lhářů hưře detekovatelné ve srovnání s videozáznamem. Podle nich je důvodem skutečnost, že verbální chování se dá kontrolovat lépe než neverbální. Další výzkumníci zjistili, že lépe detekovatelné jsou lži lidí, kteří jsou motivováni něčím, co se dotýká jejich identity (,když to zvládnete, jste inteligentní“), než pokud jsou motivováni materiálně (DePaulo a kol. 2003).

Čas na promyšlení sdělení. De Paulo a kol. (2003) zjistili, že hưře určitelná je pravdivost či lživost u těch zpráv, které byly déle plánovány. Co se týče nápovědí, u neplánovaných zpráv se prodlužuje zejména délka času mezi jednotlivými lživými odpověd'mi oproti odpovědím pravdivým.

Expert či amatér. Většina výzkumů neprokázala žádný rozdíl v úspěšnosti určení lží mezi experty (psychologové, policisté...) a běžnou populací (Bond, DePaulo 2006). Pokud se však respondenti z dané odborné skupiny rozhodovali v pro ně známém prostředí, byly 
výsledky lepší než u běžné populace - lepší detekce lhaní ve známých situacích tak byla zjištěna u policejních důstojníků (Mann, Vrij, Bull 2004), amerických federálních vyšetřovatelů, soudců, šerifů a klinických psychologů (Ekman, O’Sullivan, Frank 1999). Bond (2008) ve svém vzorku našel dvě policistky, jejichž úspěšnost byla $90 \%$, což považuje za důkaz existence lidí, kteří jsou v detekci lží experty.

Trénink. Je sporné, zda se lidská schopnost odhadnout lež dá zlepšit pomocí (krátkého) tréninkového programu - např. Kassin a Fong (1999) po hodinové instruktáži u studentů zlepšení nezaznamenali. Zlepšení po třech přednáškách u armádních úředníků nezjistili ani George, Biros, Burgoon a Nunamaker (2003). U tréninku na specifickou situaci je však možno dosáhnout dobrých výsledků - trénink výslechu u vzorku policistů sledovaných Hartwigem, Granhagem, Strömwallem a Kronkvistem (2006) vedl až k 85\% přesnosti detekce lhaní u vyslýchaných.

Pohlaví. Ve vzorku Forresta a Feldmana (2000) určovaly lživost zprávy přesněji ženy než muži. Tento výsledek však nejspiše závisí na médiu: Anderson, DePaulo, Ansfield, Tickle a Green (1999) zjistili, že zatímco muži se při detekci lhaní věnují spíše verbálním vjemům, pro ženy jsou důležité spíše vjemy vizuální; to je pak může zvýhodňovat při komunikaci tvárí v tvář. Z uvedených zjištění můžeme usoudit, že lepší výsledky žen u Forresta a Feldmana lze přisoudit dostupnosti neverbálních signálů. Díky jejich neprítomnosti na internetu se v tomto prostředí rozdíl v přesnosti detekce lži mezi pohlavími projevit nemusí.

Vynaložená mentální kapacita. Feeley a Young (2000) zjistili, že u audiovizuálního vjemu dokáží lépe detekovat lež lidé, kteří nemohou detekci věnovat plnou pozornost a věnují se ještě dalšímu úkolu. Bond a DePaulo (2006) si myslí, že je to tím, že nemají čas přemýšlet o (chybných) stereotypech týkajících se toho, jak má vypadat lhár. $\mathrm{V}$ tom př́padě by tato závislost úspěšnosti detekce na momentální kognitivní kapacitě mohla být nalezena i u internetové komunikace. Pokud je však tento vztah způsoben spíše tím, že se vytížení posuzovatelé soustředí na periferní vjemy (tedy neverbální chování pozorovaného), u internetové komunikace tato souvislost být nalezena nemusí.

Nálada. Forgas a East (2008) uvádí, že lidé mající špatnou náladu rozeznají lhaní přesněji než lidé naladěni pozitivně.

Osobnost lháře. Riggio a Friedman (1983) zjistili, že hưrèe detekovatelné jsou lži osob s vyšší potřebou dominance a exhibice, zejména ovšem tehdy, pokud je vidět jejich obličej a tělo.

Osobnost posuzovatele. Není nám znám žádný zjištěný výsledek týkající se vztahu mezi některou osobnostní charakteristikou a lepší schopností detekovat lež. Porter, Campbell, Stapleton a Birt (2002) ukázali, že tato schopnost nesouvisí s dimenzemi osobnosti Velké pětky (Extraverze, Neuroticismus, Př́ívětivost, Svědomitost a Intelekt).

\section{Automatizace}

Z výše uvedeného vyplývá, že lidé nejsou nijak zvlášt’ dobrými „detektory lži“, že je obtížné najít člověka, který by byl v detekci lží lepší než ostatní, a situaci, v níž by dokázal lež snadněji odhalit, př́padně, že je těžké takového člověka vytrénovat. 
Řešením je zapojení výpočetní techniky a automatická detekce lhaní: Vrij a Mann (2004) vyvinuli diskriminační funkci využívající různých informací o sledované (anglické) komunikaci k odlišení pravdy od lži, kterou vyzkoušeli na několika souborech dat. Úspěšnost detekce byla $79-88 \%$.

K vývoji automatické detekce lhaní u textových dat v českém jazyce se snaží přispět empirická část našeho článku, v níž se pokoušíme najít s využitím automaticky zjištovaných informací rozdíly mezi pravdivou a lživou komunikací.

\section{Nápovědi pro detekci lhaní}

Při sledování chování a projevu klamajících lidí můžeme najít charakteristiky (nápovědi), v nichž se pravdivá a lživá komunikace liší. Mnoho těchto nápovědí je dostupných, pouze pokud lháře vidíme nebo slyšíme, některé se však mohou vyskytnout i v textové formě projevu. V Tabulce 1 uvádíme nápovědi, které vyšly jako statisticky významně odlišující pravdivou a lživou komunikaci v metaanalýze 120 studí provedené DePaulo a kol. (2003) nebo statisticky významně odlišovaly pravdivou a lživou komunikaci u některých ze 46 studií shrnovaných Vrijem (2000). Vybíráme přitom ty nápovědi, které by mohly být nalezeny v textové komunikaci.

Tabulka 1: Nápovědi pro rozlišení mezi pravdou a lží

\begin{tabular}{|l|l|l|}
\hline Nápověd' & Popis & Kde je častější/vyšší \\
\hline $\begin{array}{l}\text { Čas vynaložený } \\
\text { na mluvení }\end{array}$ & $\begin{array}{l}\text { Podíl celkové doby interakce, kdy mluvčí } \\
\text { mluvil. }\end{array}$ & Pravda \\
\hline Detaily & $\begin{array}{l}\text { Množství detailů (lidé, věci, události: v jakém } \\
\text { šly pořadí, na jakém místě...) }\end{array}$ & Pravda \\
\hline Přijatelnost & $\begin{array}{l}\text { Míra, v níž tvrzení vypadá přijatelně či } \\
\text { uvěritelně }\end{array}$ & Pravda \\
\hline $\begin{array}{l}\text { Logická } \\
\text { struktura }\end{array}$ & $\begin{array}{l}\text { Konzistence a koherence jednotlivých } \\
\text { uváděných detailů mezi sebou }\end{array}$ & Pravda \\
\hline Zmatenost & Mluvčí působí zmateně & Pravda \\
\hline Zaujatost & Mluvčí působí, že je tématem zaujat & Pravda \\
\hline $\begin{array}{l}\text { Bezprostřednost } \\
\text { (immediacy) } \\
\text { mluvčího }\end{array}$ & $\begin{array}{l}\text { Mluvčí se snaží udržet menší vzdálenost od } \\
\text { popisovaného; blíze k ději je tehdy, pokud } \\
\text { použije př́itomný čas místo budoucího či } \\
\text { minulého, aktivní tvar místo pasivního, „toto“ } \\
\text { místo „támhleto“ }\end{array}$ & Pravda \\
\hline $\begin{array}{l}\text { Vnímaná } \\
\text { bezprostřednost }\end{array}$ & $\begin{array}{l}\text { Mluvčí je komunikačním partnerem vnímán } \\
\text { jako více vtažený do komunikace, méně si } \\
\text { držíí odstup }\end{array}$ & Pravda \\
\hline
\end{tabular}




\begin{tabular}{|c|c|c|}
\hline Nápověd' & Popis & Kde je častější/vyšší \\
\hline $\begin{array}{l}\text { Vnímaná } \\
\text { sebejistota }\end{array}$ & $\begin{array}{l}\text { Mluvčí působí na druhého jistě, je asertivní, } \\
\text { důrazný }\end{array}$ & Lež \\
\hline $\begin{array}{l}\text { Opravování sebe } \\
\text { sama }\end{array}$ & Jak často mluvčí opravuje, co řekl & Pravda \\
\hline $\begin{array}{l}\text { Připuštění ztráty } \\
\text { paméti }\end{array}$ & Jak často mluvčí připustí, že něco zapomněl & Pravda \\
\hline Počet segmentů & Celkový počet zpráv v komunikaci & Pravda \\
\hline $\begin{array}{l}\text { Tvrzení } \\
\text { príipouštějici } \\
\text { pochybnosti }\end{array}$ & $\begin{array}{l}\text { Jak často mluvčí připustí, že o něčem } \\
\text { pochybuje; tj. použije slov jako „,možná“, } \\
\text { „,snad“, „,myslím si““, „zdá se mi“. }\end{array}$ & Pravda \\
\hline Modifikátory & $\begin{array}{l}\text { Jak často mluvčí situaci upřesňuje použitím } \\
\text { výrazů typu „někdy“, „občas“ }\end{array}$ & Pravda \\
\hline $\begin{array}{l}\text { Odkazy na } \\
\text { odpovédnost }\end{array}$ & $\begin{array}{l}\text { Jak často mluvčí mluví o tom, že někdo za } \\
\text { něco nese zodpovědnost, at' už on sám nebo } \\
\text { někdo jiný }\end{array}$ & Pravda \\
\hline $\begin{array}{l}\text { Opakování částí } \\
\text { zprávy }\end{array}$ & $\begin{array}{l}\text { Jak často mluvčí opakuje již jednou vyřčené } \\
\text { informace }\end{array}$ & Pravda \\
\hline Počet přereknutí & $\begin{array}{l}\text { Počet špatně vyslovených slov, dvakrát za } \\
\text { sebou vyslovených slov, nedokončených vět } \\
\text { apod. }\end{array}$ & Lež \\
\hline Negativní tvrzení & $\begin{array}{l}\text { Počet tvrzení vyjadřujících averzi k nějakému } \\
\text { objektu, osobě či názoru, případně tvrzení } \\
\text { vyjadřujících špatnou náladu }\end{array}$ & Lež \\
\hline $\begin{array}{l}\text { Irelevantni } \\
\text { informace }\end{array}$ & $\begin{array}{l}\text { Počet tvrzení, na něž se nikdo neptal a která } \\
\text { nemají co do činění s projednávaným } \\
\text { tématem }\end{array}$ & Lež \\
\hline $\begin{array}{l}\text { Generalizovaná } \\
\text { tvrzení }\end{array}$ & $\begin{array}{l}\text { Užití slov jako „každý“, „,ž̌dycky“, „,nikdo“, } \\
\text { „nikdy“ }\end{array}$ & Lež \\
\hline
\end{tabular}

V Tabulce 2 uvádíme dohromady nápovědi sledované ve třech studiích, které pro detekci rozdílů mezi pravdivým a lživým textem použily automatickou lingvistickou analýzu (v angličtině). O podobnou analýzu v češtině se pokusíme i my v další části tohoto článku. Citované studie jsou analýza přepisu videonahrávek z výzkumu se 120 respondenty (Burgoon, Qin 2006), analýza přepisů pěti studií s celkově 300 respondenty (Newman a kol. 2003) a analýza emailové komunikace 60 respondentů, kteří měli za úkol si domluvit pořadí věcí, které by si vzali s sebou při havárii uprostřed pouště (Zhou, Burgoon, Nunamaker, Twitchell 2004). Pokud bylo v alespoň některé ze tř́ studií zjištěno, že daná charakteristika je vy̌šśí př̌i pravdivé komunikaci, je uvedena v řádku Pravda. Bylo-li alespoň v jedné ze tří studií zjištěno, že je 
častější při komunikaci lživé, uvádíme ji v ráádku Lež. Navzájem rozporné výsledky v tabulce neuvádíme a diskutujeme je níže.

U počtu slov, počtu sloves, počtu podstatných jmen, počtu vět, počtu zájmen $\mathrm{v}$ první osobě množného čísla a počtu modifikátoru (každý apod.) se výsledky lišily. Zatímco u Burgoon a Qin (2006), kdy šlo o komunikaci tváŕí v tváŕ, byly tyto charakteristiky vyšší u pravdu mluvících lidí, u Zhou a kol. (2004) byly při emailové komunikaci vyšší u klamajících lidí. Je tedy možné, že u online komunikace se lingvistické nápovědi pro lživost daného sdělení projevují jinak (a opačně) než u komunikace vedené offline.

V rámci studie Zhou a kol. (2004) autoři rovněž sledovali, jak se nápovědi budou měnit během tří dnů trvání výzkumu. Tedy zda se klamající osoby dokáží na komunikaci adaptovat a nápovědi přestat emitovat. Ukázalo se, že první dva dny klamající osoby napsaly větší počet slov, sloves, modifikátorů, podstatných jmen a vět, jejich emaily naopak obsahovaly méně různých slov a byly méně rozmanité i co do obsahu. Tyto rozdíly se třetí den vytratily. Pouze druhý den se u klamajících osob objevil větší počet sebereferencí a menší počet zobecnujících výrazů, tyto rozdíly mezi pravdu mluvícími a klamajícími respondenty se neobjevily první ani třetí den. První den klamající používali více slov s negativním nábojem, druhý a třetí den se tento rozdíl vytratil, třetí den naopak klamající použili více slov s pozitivním nábojem (Zhou, Burgoon a Twitchell 2003). Zdá se tedy, že klamající lidé se na komunikaci přes internet dokáží adaptovat a emitované nápovědi pozměnit. Tím můžeme vysvětlit vyšší počet slov s pozitivním nábojem a počet modálních sloves vysledovaný u Zhou a kol. (2004) - což je v rozporu se zjištěním DePaula a kol. (2003) u komunikace offline. Většina studií analyzovaných DePaulo a kol. (2003) přitom respondentům majícím za úkol lhát podobnou přípravu neumožnila. Vysvětlením pro pozitivní emoce i počet modálních sloves může být také to, že u Zhou a kol. (2004) šlo o hru, a klamající respondenti tak mohli komunikaci považovat za zábavnější a cítit se lépe.

Tabulka 2: Nápovědi pro rozlišení mezi pravdou a lží - automatická detekce s pomocí lingvistického softwaru

\begin{tabular}{|l|l|}
\hline $\begin{array}{l}\text { Nápovědi častější } \\
\text { při pravdivé } \\
\text { komunikaci }\end{array}$ & $\begin{array}{l}\text { Počet různých slov, podíl senzorických slov ku celkovému počtu } \\
\text { slov, počet zájmen v první osobě, počet zájmen v první osobě } \\
\text { množného čísla, počet zájmen ve tretí osob̌e, podíl počtu př́slovcí } \\
\text { a adjektiv k počtu podstatných jmen a sloves (emotivita), počet } \\
\text { slov popisujících proces percepce (vidět, dotýkat se), počet } \\
\text { slov popisujících exkluzi (bez, s výjimkou), počet znamének } \\
\text { oddělujících části věty / počet vět, počet rüzných slov / počet slov, } \\
\text { počet různých slov majících význam (=obsažených ve slovníku) / } \\
\text { počet všech slov majících význam }\end{array}$ \\
\hline $\begin{array}{l}\text { Nápovědi } \\
\text { vyskytující se } \\
\text { častěji při lživé } \\
\text { komunikaci }\end{array}$ & $\begin{array}{l}\text { Průměrná délka věty, počet mezer, počet opakujících se slov, } \\
\text { počet zájmen ve druhé osobě, počet členů (a, an, the), počet slov } \\
\text { týkajích se negativních emocí, počet slov označujících pohyb } \\
\text { (chodit), počet překlepů / počet slov }\end{array}$ \\
\hline
\end{tabular}


Zhou, Burgoon, Zhang a Nunamaker (2004) se ve svém experimentu dále snažili zjistit, jak se mění pozice lhářu během emailové komunikace z hlediska jejich submisivity / dominance v komunikaci. U většiny ze sedmi sledovaných lingvistických proměnných zjistili, že klamající osoby první den začínaly ze submisivnější pozice a postupně se stávaly dominantnějšími (u vyjádření pozitivních pocitů, jeho expresivity a intenzity došlo k nárůstu, u nejasnosti vyjadřování nejdříve k poklesu a pak k nárůstu). To vysvětlují tím, že klamající nejprve chtějí navázat dobrý vztah s klamanými, takže volí vyčkávací taktiku. Jakmile je vztah navázán, je pro ně naopak výhodné, aby byl komunikační partner co nejméně aktivní, aby se konverzace nevyvinula směrem, který by mohl vést k jejich odhalení. Proto se postupně stávají dominantnějšími.

Co se týče dalších výzkumů sledujících nápovědi pro lhaní při online komunikaci na internetu, našli jsme jich mimo již citovaný výzkum Zhou a kol. (2003, 2004) jen několik: U Giordana, Stonera, Brouera a George (2007) uváděli klamající při IM komunikaci více detailů, častěji se spontánně opravovali a vyjadřovali se o komunikovaných skutečnostech více neprímo. Twitchell, Frosgren, Wiers, Burgoon a Nunamaker (2005) nechali své respondenty hrát počítačovou hru, při níž respondenti se svými spoluhráči komunikovali na chatu, někteří z nich přitom měli za úkol spoluhráče oklamat. Klamající hráči měli větší počet replik a častěji se druhých ptali. V dalším výzkumu Twitchella, Nunamakera a Burgoon (2004) psali klamající hráči na chatu více nejasné příspěvky.

\section{Cíl studie}

V následující studii chceme ukázat, jaké jsou rozdíly v lingvistických a dalších automaticky detekovatelných charakteristikách zpráv Windows Live Messengeru produkovaných lidmi prezentujícími sami sebe a prezentujícími falešnou identitu. Zajímalo nás, zda existují automaticky detekovatelné charakteristiky, které by mohly napomoci odhalování lží na internetu. Respondenty jsme proto nejprve nechali konverzovat s druhou osobou, a poté jim dali úkol jiné osobě lhát. Nakonec jsme vyhodnotili lingvistické charakteristiky v obou konverzacích a porovnali rozdíly. Experiment byl součástí širšího výzkumu týkajícího se kromě lhaní i přesnosti odhadu osobnosti druhého člověka po komunikaci na internetu. Výsledky tohoto výzkumu plánujeme zveřejnit $\mathrm{v}$ budoucnu.

Windows Live Messenger 8.1 použitý v komunikaci mezi respondenty je tzv. Instant Messenger: nástroj sloužící pro textovou komunikaci v reálném čase mezi dvěma lidmi, kteří si vyměňují krátké vzkazy. Umožňuje vidět celou historii komunikace a posílat si obrázky a emotikony.

\section{Vzorek}

Zkoumaný vzorek tvořilo 28 respondentů, jejichž komunikačními partnery bylo 28 studentů Fakulty sociálních studií (FSS) Masarykovy univerzity. Část vzorku, 21 respondentů, byla oslovena prvním autorem, který se snažil získat osoby, u nichž bude vysoká pravděpodobnost, že neznají nikoho ze studentů Fakulty sociálních studií, kteří poté byli jejich komunikačními partnery. Zbylých 7 respondentů odpovědělo na inzerát zveřejněný v Informačním 
systému Masarykovy univerzity. Devět z takto získaného celkového počtu byli studenti vyšších ročníků Fakulty sociálních studií. Dalších 17 osob byli studenti jiných fakult Masarykovy univerzity a jiných vysokých škol v Brně. Zbylí dva respondenti byli nedávní absolventi Masarykovy univerzity. Mezi respondenty bylo 15 žen a 13 mužů. Věk respondentů-mužů se pohyboval mezi 20 a 33 lety, průměr 25,3 roku. Věk respondentek byl mezi 20 a 28 lety, průměr 24,5 roku. Věk jejich komunikačních partnerů byl mezi 19 a 29 lety, průměr 22 let. Respondentům bylo při náboru řečeno, že se budou účastnit výzkumu toho, jak si lidé utvářejí názor na neznámou osobu na internetu.

\section{Průběh výzkumu}

Respondenti byli posazeni do počítačové učebny, jejich komunikační partneři do jiné učebny $\mathrm{v}$ jiné budově, aby se nemohli potkat. Komunikační partner byl každému respondentovi náhodně priiřazen, přičemž bylo zároveň dbáno na to, aby byla co největší pravděpodobnost, že se navzájem neznají (respondentům z vyšších ročníků Fakulty sociálních studií tak byli priiřazeni partneři z prvních dvou ročníků). $V$ každé učebně průběh řídili dva administrátoři.

Každý účastník na začátku dostal číslo komunikačního partnera stejného pohlaví z druhé učebny a papírek s instrukcí, že se má druhé osobě představit, komunikovat s ní 40 minut přes Windows Live Messenger a utvořit si na ni názor. Komunikační partneři dostali stejnou instrukci. Po 40 minutách byla konverzace zastavena a respondenti vyplnili dva dotazníky. Respondentům byla poté dána písemná instrukce, že mají 10 minut na to, aby si vymysleli identitu osoby opačného pohlaví, a tuto identitu poté prezentovali při konverzaci. Bylo jim zdůrazněno, že informace si mají skutečně vymyslet a ne se prezentovat jako někdo známý z jejich okolí (např. partner). Dále bylo zdůrazněno, že osoba na druhé straně se nesmí dozvědět, že si vymýšlejí, proto mají v prrípadě podezření zapírat. Nakonec jim bylo řečeno, že ne každý podobný úkol zvládne, a proto deset z nich, kteří dokáží nejlépe oklamat osobu v druhé učebně, dostane čokoládu. Poté jim byl náhodně přiřazen partner opačného pohlaví z druhé učebny (dvě ženy vzhledem $\mathrm{k}$ nedostatku mužů dostaly partnerku stejného pohlaví, vůči které hrály roli muže), s nímž opět 40 minut komunikovali. Osobám sloužícím jako komunikační partneři bylo řečeno, že mají 15 minut přestávku, a poté celá procedura proběhne ještě jednou, protože potřebujeme více dat. Totéž bylo řečeno jednomu $\mathrm{z}$ administrátorů.

Níže analyzujeme jako vzorek lživé komunikace vzkazy respondentů z jejich druhé konverzace, kdy měli za úkol prezentovat falešnou identitu. Jako vzorek pravdivé komunikace bereme vzkazy, které napsali stejní respondenti během první konverzace, kdy nevěděli o tom, že za chvíli dostanou za úkol lhát.

\section{Lingvistická analýza}

U všech konverzací jsme nejprve (ručně, podle textu konverzace) stanovili začátek a konec vlastní konverzace, abychom z dalšího zpracování odstranili úvodní a závěrečné pozdravné fráze, různé organizační poznámky či informace o př́padných technických problémech na jedné či druhé straně atp. $Z$ jednotlivých konverzací jsme pak vyjmuli zprávy 
sledovaných respondentů. Protože někteří respondenti psali bez diakritiky, doplnili jsme ji v jejich konverzacích poloautomaticky ručním výběrem z možností nabízených morfologickým analyzátorem ajka (Sedláček, Smrž 2001). Poté jsme data předložili opět analyzátoru ajka, abychom ke každému slovu získali jeho možná lemmata (základní tvary) a k nim příslušející možné morfologické značky (symbolická vyjádření hodnot gramatických kategorií). Možná lemmata a značky analyzátoru ajka neznámých slov odhadl podle jejich zakončení tzv. guesser (zatím nepublikováno), čímž bylo pokryto i velké množství slov obsahujících překlepy, slov všelijak zkomolených atp. (slova hovorová či nespisovná rozpoznal už přímo analyzátor ajka).

Takto jsme získali vstup pro morfologický desambiguátor (Šmerk 2008), který na základě kontextu u všech slov vybere jedno lemma a značku, tedy desambiguuje, zjednoznační výstup morfologické analýzy. Úspěšnost desambiguátoru byla při jeho testování na novinových článcích přes 95 \%. Na našich datech jsme jej ověřili na jedné náhodně vybrané konverzaci, jeho úspěšnost byla $85,2 \%$. Úspěšnost měříme jako následující podíl: počet informací správně zjištěných desambiguátorem / (počet informací správně zjištěných desambiguátorem + počet informací jsoucích v textu a chybně nezjištěných desambiguátorem + počet informací nejsoucích v textu a chybně zjištěných desambiguátorem). Jako jednu ,informaci“ zde bereme například zjištění „1. pád“; u slova „velký“ tedy máme tři informace: „přídavné jméno“, „1. pád“, „1. stupeň“. Horší úspěšnost desambiguátoru na internetové konverzaci ve srovnání s novinovými články je zpo̊sobena tím, že respondenti používali nespisovný jazyk.

V Tabulce 3 uvádíme charakteristiky, které jsme měřili. Kromě posledních tří charakteristik jsme všechny ostatní naměřené hodnoty normalizovali délkou dané konverzace (tj. vydělili počtem znaků, které respondent v dané konverzaci napsal a vynásobili tisíci), aby se vyrovnaly případné rozdíly v délce první a druhé konverzace. Pokud na základě výše uvedených výzkumů prováděných v angličtině předpokládáme nějaké zjištění, uvádíme ho v pravém sloupci.

Tabulka 3: Charakteristiky měřené v rámci experimentu

\begin{tabular}{|l|l|l|}
\hline Charakteristika & $\begin{array}{l}\text { Předpokládaná vyšší míra u } \\
\text { (pravda / lež) }\end{array}$ & $\begin{array}{l}\text { Počet v celém } \\
\text { souboru }\end{array}$ \\
\hline $\begin{array}{l}\text { Počet vět (počet částí } \\
\text { zpráv oddělených tečkami, } \\
\text { otazníky, vykřičníky } \\
\text { a emotikony) }\end{array}$ & $\begin{array}{l}\text { Pravda - vzhledem k normování počtem } \\
\text { znaků odpovídá vyšší míra tohoto údaje } \\
\text { menší průměrné délce věty, protože } \\
\text { na věty je rozdělena celá konverzace. } \\
\text { Průměrná délka věty byla jako vyšší } \\
\text { zjištěna u lživých konverzací u Burgoon } \\
\text { a Qin (2006). }\end{array}$ & 4646 \\
\hline $\begin{array}{l}\text { Počet částí vět (totéž jako } \\
\text { předchozí, oddělovačem } \\
\text { může být navíc i čárka) }\end{array}$ & $\begin{array}{l}\text { Pravda - totéž jako předchozí, liší se } \\
\text { pouze započítáním čárek. }\end{array}$ & 7112 \\
\hline
\end{tabular}




\begin{tabular}{|c|c|c|}
\hline Charakteristika & $\begin{array}{l}\text { Předpokládaná vyšší míra u } \\
\text { (pravda / lež) }\end{array}$ & $\begin{array}{l}\text { Počet } \mathrm{v} \text { celém } \\
\text { souboru }\end{array}$ \\
\hline Počet emotikonů & & 1163 \\
\hline $\begin{array}{l}\text { Počet otázek (počet } \\
\text { otazníků; více otazníků za } \\
\text { sebou počítáno jako jeden) }\end{array}$ & & 849 \\
\hline 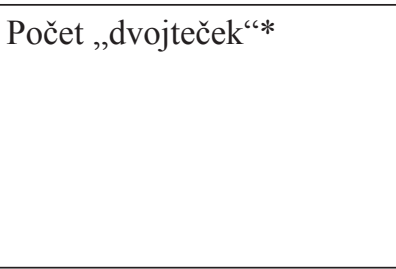 & $\begin{array}{l}\text { Lež - domníváme se, že dvoj- či trojtečky } \\
\text { mohou být používány tehdy, když } \\
\text { mluvčí chce zamlčet zbytek věty nebo } \\
\text { neví, co sdělit - tak by se mohli chovat } \\
\text { respondenti, kteří nechtějí dát najevo svou } \\
\text { nejistotu vyplývající ze lhaní. }\end{array}$ & 979 \\
\hline Počet troj- a více-teček & Lež - totéž jako předchozí. & 795 \\
\hline Počet podstatných jmen & & 5828 \\
\hline Počet př́idavných jmen & & 1602 \\
\hline Počet zájmen & & 5671 \\
\hline Počet číslovek & & 340 \\
\hline Počet sloves & & 6555 \\
\hline Počet příslovcí & & 3552 \\
\hline Počet předložek & & 2475 \\
\hline Počet spojek & & 3219 \\
\hline Počet částic & & 2096 \\
\hline Počet citoslovcí & & 130 \\
\hline Počet slov v 1. pádě & & 5192 \\
\hline Počet slov v 2. pádě & & 1878 \\
\hline Počet slov v 3. pádě & & 904 \\
\hline Počet slov v 4. pádě & & 4995 \\
\hline Počet slov v 5. pádě & & 26 \\
\hline Počet slov v 6. pádě & & 1850 \\
\hline Počet slov v 7. pádě & & 934 \\
\hline $\begin{array}{l}\text { Počet slov v 1. stupni } \\
\text { (počet přídavných jmen } \\
\text { a př́slovcí v 1. stupni) }\end{array}$ & & 4907 \\
\hline Počet slov v 2. stupni & & 198 \\
\hline Počet slov v 3. stupni & & 49 \\
\hline
\end{tabular}




\begin{tabular}{|l|l|l|}
\hline Charakteristika & $\begin{array}{l}\text { Předpokládaná vyšší míra u } \\
\text { (pravda / lež) }\end{array}$ & $\begin{array}{l}\text { Počet v celém } \\
\text { souboru }\end{array}$ \\
\hline $\begin{array}{l}\text { Počet slovesných tvarů } \\
\text { a zájmen v 1. osobě }\end{array}$ & $\begin{array}{l}\text { Pravda - počet zájmen v první osobě } \\
\text { byl vyšší pro pravdivou komunikaci } \\
\text { u Burgoon a Qin (2006) a Newman a kol. } \\
(2003) .\end{array}$ & 2939 \\
\hline $\begin{array}{l}\text { Počet slovesných tvarů } \\
\text { a zájmen v 2. osobě }\end{array}$ & & 1183 \\
\hline $\begin{array}{l}\text { Počet slovesných tvarů } \\
\text { a zájmen v 3. osobě }\end{array}$ & $\begin{array}{l}\text { Lež - podíl počtu adjektiv a př́íslovcí vǔčí } \\
\text { podstatným jménům a slovesům byl vyšśí } \\
\text { pro pravdivou komunikaci u Burgoon } \\
\text { a Qin (2006). }\end{array}$ & NA \\
\hline $\begin{array}{l}\text { Poměr sloves } \\
\text { a podstatných jmen ku } \\
\text { př́́davným jménumm } \\
\text { a příslovcím }\end{array}$ & & NA \\
\hline Průměrná délka slova & $\begin{array}{l}\text { Lež - obdobně jako u délky věty (viz } \\
\text { počet vět), tyto charakteristiky spolu } \\
\text { mohou souviset. }\end{array}$ & NA \\
\hline $\begin{array}{l}\text { Průměrná délka } \\
\text { jednotlivých replik (zprával }\end{array}$ & \\
\hline
\end{tabular}

* Respondenti někdy místo trojtečky psali pouze dvě tečky.

Pro porovnání výše uvedených charakteristik pravdivých a lživých vzkazů jsme použili t-test pro párované proměnné. Pokud některá z proměnných neměla normální rozložení, použili jsme pro jejich porovnání Wilcoxonův test pro dva závislé výběry.

\section{Výsledky}

Výsledky uvádíme v Tabulce 4. U lživé komunikace jsme na pětiprocentní hladině významnosti zjistili vyšší počet příslovcí, počet př́islovcí a prrídavných jmen v prvním stupni, počet vět, počet částí vět a počet otázek. U pravdivé komunikace byl vyšší počet slov ve druhém pádě, počet číslovek, větší průměrná délka messengerových vzkazů a vyšší poměr podstatných jmen a sloves ku př́idavným jménům a př́slovcím. 


\begin{tabular}{|c|c|c|c|c|c|c|c|c|c|c|c|c|c|c|}
\hline 兽 & 용 & 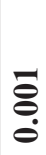 & $\begin{array}{l}\infty \\
\infty \\
? \\
0\end{array}$ & 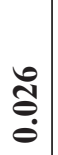 & $\frac{O}{\mathfrak{n}}$ & $\frac{n}{n}$ & $\begin{array}{l}n \\
n \\
n \\
0\end{array}$ & \begin{tabular}{l}
0 \\
\multirow{6}{0}{} \\
0
\end{tabular} & $\begin{array}{l}n \\
\infty \\
\vdots \\
0\end{array}$ & $\begin{array}{c}\text { } \\
\dot{\theta} \\
\dot{\theta}\end{array}$ & $\mid \begin{array}{c}1 \\
\sigma \\
0 \\
0\end{array}$ & $\begin{array}{l}0 \\
\stackrel{8}{0} \\
\dot{0}\end{array}$ & \begin{tabular}{l}
$\infty$ \\
\multirow{1}{+}{} \\
$\vdots$ \\
0
\end{tabular} & $\bar{n}$ \\
\hline 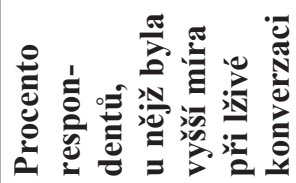 & $\begin{array}{l}0 \\
\infty \\
0\end{array}$ & $\begin{array}{l}\partial^{\circ} \\
\text { a }\end{array}$ & $\begin{array}{l}0^{0} \\
\stackrel{n}{n}\end{array}$ & $\begin{array}{l}0 \\
2 \\
2\end{array}$ & $\begin{array}{l}\partial^{0} \\
\dot{\theta}\end{array}$ & $\begin{array}{l}\text { de } \\
\text { in }\end{array}$ & $\frac{d^{0}}{i n}$ & $\frac{\partial^{0}}{i n}$ & $\begin{array}{l}\partial^{0} \\
\dot{n}\end{array}$ & $\begin{array}{l}\partial^{0} \\
\text { సे }\end{array}$ & $\begin{array}{l}\partial^{0} \\
0 \\
i n\end{array}$ & $\frac{0^{\circ}}{\nabla}$ & $\begin{array}{l}\partial^{\circ} \\
i n\end{array}$ & $\stackrel{\partial}{\stackrel{\partial}{+}}$ \\
\hline 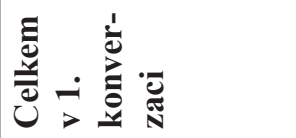 & तે & $\begin{array}{l}\mathcal{O} \\
\text { n } \\
m\end{array}$ & ఫర & $\begin{array}{l}\mathcal{O} \\
+\end{array}$ & $\underset{+}{+}$ & ?̊ & \begin{tabular}{l}
$\infty$ \\
$\stackrel{\infty}{\sim}$ \\
\multirow{2}{*}{}
\end{tabular} & $\sqrt{2}$ & \begin{tabular}{l}
$\infty$ \\
\multirow{\sigma}{\sim}{} \\
$\sim$
\end{tabular} & $\stackrel{ \pm}{\beth}$ & $\mid \begin{array}{c}n \\
\hat{D} \\
\end{array}$ & $\stackrel{n}{n}$ & $\begin{array}{l}\bullet \\
\stackrel{0}{二} \\
=\end{array}$ & g \\
\hline 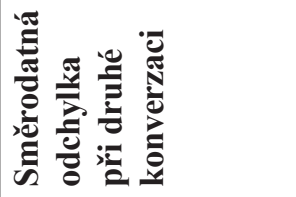 & $\stackrel{N}{N}$ & $\infty$ & $\stackrel{\gamma}{\sigma}$ & $\begin{array}{l}0 \\
ن \\
ن\end{array}$ & $n$ & $n$ & Ғ & $\tilde{n}$ & $\begin{array}{l}0 \\
i\end{array}$ & $\begin{array}{l}\infty \\
0 \\
0\end{array}$ & $\vec{r}$ & $\begin{array}{l}\infty \\
\sim \\
\sim\end{array}$ & $\stackrel{n}{\sim}$ & $\vec{r}$ \\
\hline 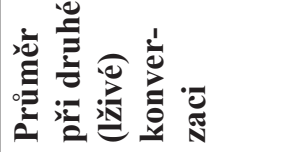 & $\stackrel{\circ}{\stackrel{2}{2}}$ & $\stackrel{m}{\sigma}$ & $\begin{array}{l}\infty \\
\dot{r}\end{array}$ & $\begin{array}{l}a \\
\dot{n}\end{array}$ & $\begin{array}{l}0 \\
i \\
i\end{array}$ & $\begin{array}{l}0 \\
\dot{\sigma}\end{array}$ & $\stackrel{+}{m}$ & $\stackrel{\nabla}{\sigma}$ & $\stackrel{\infty}{\dot{m}}$ & $\because$ & $\begin{array}{l}+ \\
\dot{m}\end{array}$ & $\stackrel{m}{\sim}$ & $\begin{array}{l}\dot{ \pm} \\
\pm\end{array}$ & $\stackrel{n}{\simeq}$ \\
\hline 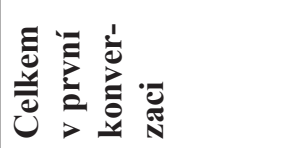 & N & $\frac{0}{6}$ & ลे & $\begin{array}{c}\infty \\
\infty \\
n\end{array}$ & 吕 & ?ִ & ঠ & $\underset{\infty}{\exists}$ & ๙ે & $\frac{0}{N}$ & $\left|\begin{array}{c}N \\
\infty \\
+ \\
m\end{array}\right|$ & ลิ & $\begin{array}{l}\stackrel{8}{0} \\
\text { = }\end{array}$ & $\stackrel{\text { }}{\text { I }}$ \\
\hline 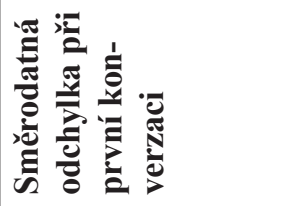 & n? & $\begin{array}{l}0 \\
\text { in }\end{array}$ & $\stackrel{\sim}{\forall}$ & $\begin{array}{l}0 \\
\dot{i}\end{array}$ & $\stackrel{\circ}{+}$ & $\stackrel{?}{\forall}$ & $\stackrel{\sim}{\forall}$ & ָָ & $\stackrel{\sim}{\forall}$ & 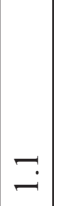 & $\hat{\sigma}$ & $\hat{\mathrm{j}}$ & $\underset{\sim}{\sim}$ & $\ddot{n}$ \\
\hline 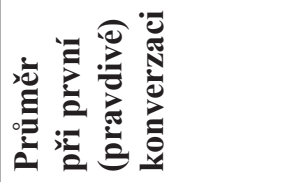 & $\begin{array}{l}0 \\
\stackrel{1}{1}\end{array}$ & $\hat{m}$ & $n$ & $\stackrel{n}{+}$ & $\vec{n}$ & $\stackrel{\sim}{\forall}$ & $\stackrel{n}{m}$ & $\vec{a}$ & $\stackrel{\infty}{\dot{m}}$ & $\stackrel{\nabla}{\sim}$ & $\begin{array}{l}\infty \\
\dot{n} \\
0\end{array}$ & $\stackrel{\Upsilon}{2}$ & $\begin{array}{l}\stackrel{+}{ \pm} \\
\pm\end{array}$ & $\vec{\infty}$ \\
\hline 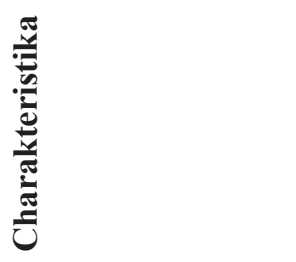 & $\begin{array}{l}10 \\
> \\
2 \\
20 \\
0 \\
0 \\
0\end{array}$ & 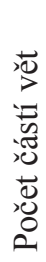 & 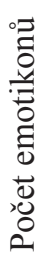 & 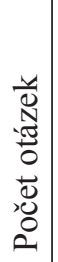 & 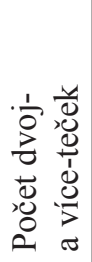 & 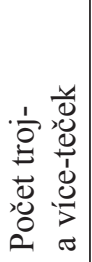 & 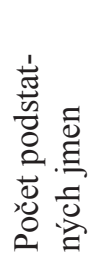 & 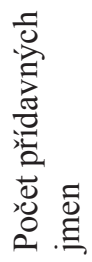 & 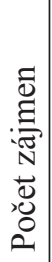 & 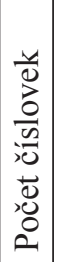 & $\mid \begin{array}{c}0 \\
0 \\
0 \\
0 \\
n \\
0 \\
0 \\
0 \\
0 \\
0\end{array}$ & 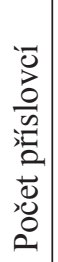 & 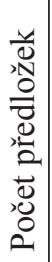 & 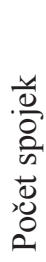 \\
\hline
\end{tabular}




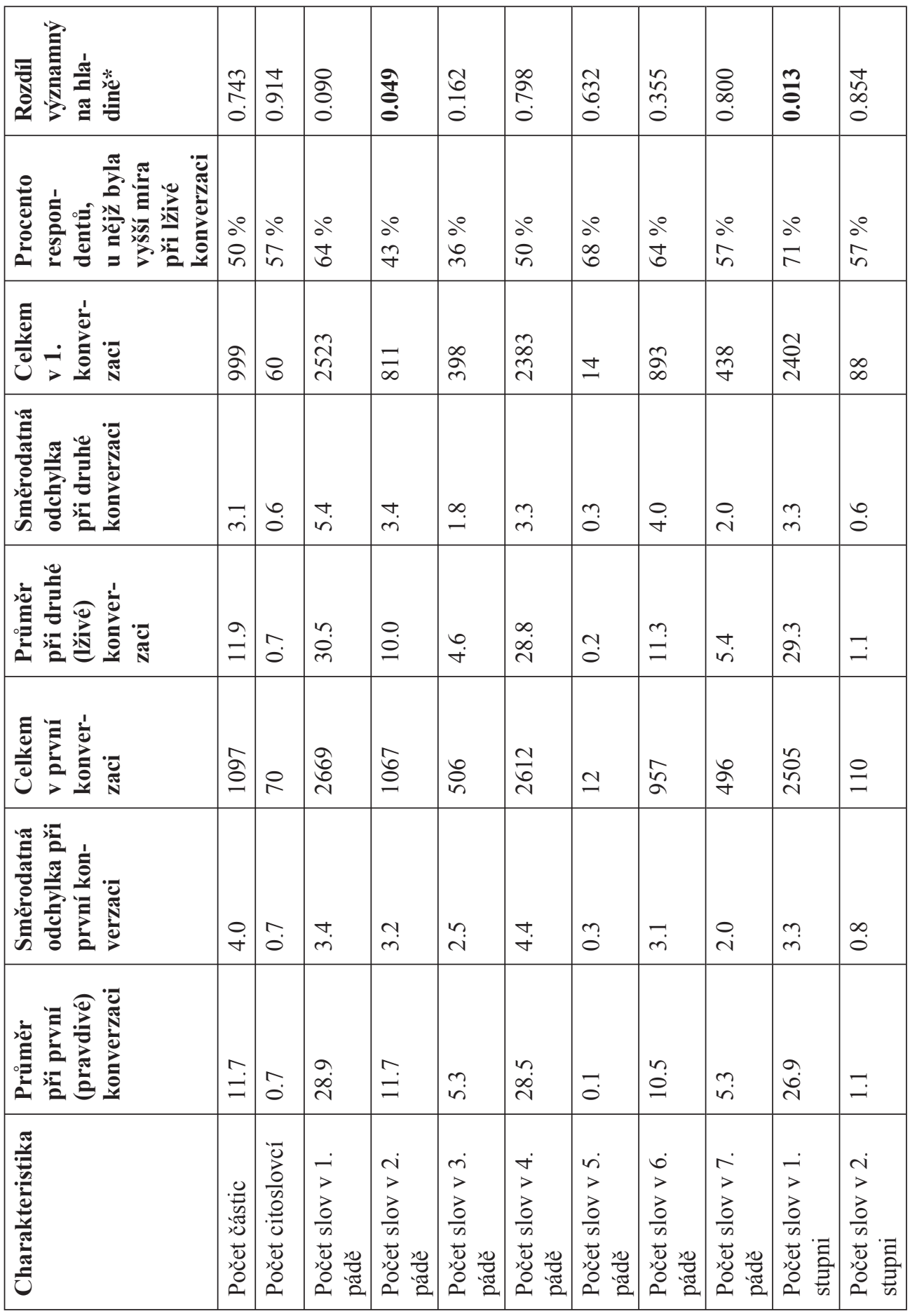


Václav Linkov, Pavel Šmerk: Rozdíly mezi pravdivou a lživou online textovou komunikací

\begin{tabular}{|c|c|c|c|c|c|c|c|}
\hline 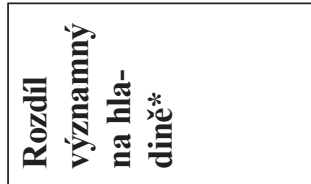 & $\stackrel{m}{\stackrel{2}{0}}$ & $\begin{array}{l}0 \\
\\
0\end{array}$ & 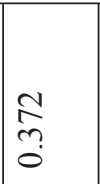 & त్రి & 足 & $\mid \begin{array}{l}\mathbb{0} \\
\infty \\
0 \\
0\end{array}$ & 令 \\
\hline 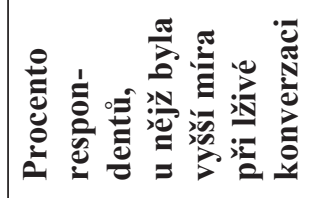 & $\begin{array}{l}a^{\circ} \\
\text { in }\end{array}$ & $\begin{array}{l}\partial^{0} \\
0 \\
0\end{array}$ & $\frac{\partial^{\circ}}{6}$ & $\begin{array}{l}0^{\circ} \\
\text { in }\end{array}$ & $\begin{array}{l}0 \\
0 \\
0 \\
i\end{array}$ & $\frac{0^{\circ}}{6}$ & $\begin{array}{l}{ }^{\circ} \\
\stackrel{\lambda}{2}\end{array}$ \\
\hline 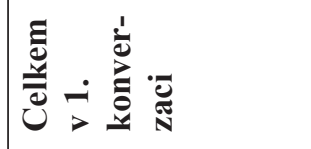 & $\stackrel{\sim}{\sim}$ & 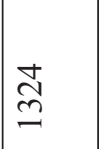 & $\vec{\infty}$ & ผิ & $\overleftrightarrow{z}$ & $\overleftrightarrow{z}$ & $\overleftrightarrow{z}$ \\
\hline 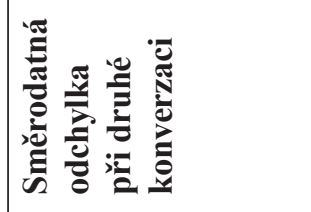 & $\stackrel{n}{0}$ & $\stackrel{\sim}{+}$ & $\vec{i}$ & $\hat{i}$ & $\stackrel{+}{\circ}$ & $\stackrel{N}{0}$ & ڤิ) \\
\hline 造 & ?? & $\begin{array}{l}a \\
i n\end{array}$ & $\stackrel{\sim}{r}$ & $\begin{array}{l}\infty \\
\stackrel{I}{I}\end{array}$ & $\stackrel{\vec{i}}{\mathrm{i}}$ & $\stackrel{\sim}{\sim}$ & $\vec{g}$ \\
\hline 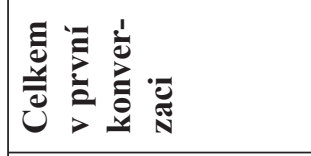 & $\tilde{\imath}$ & $\frac{n}{6}$ & రె & $\stackrel{一}{=}$ & 艺 & $\overleftrightarrow{Z}$ & $\overleftrightarrow{z}$ \\
\hline 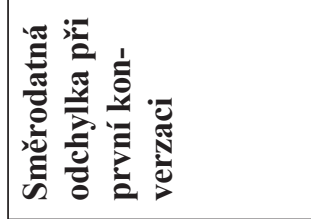 & $\stackrel{+}{0}$ & $\stackrel{\sim}{m}$ & $\ddot{n}$ & $\stackrel{\dot{r}}{\dot{r}}$ & $\stackrel{\Delta}{\circ}$ & $\stackrel{1}{0}$ & $\stackrel{\nabla}{\curvearrowright}$ \\
\hline 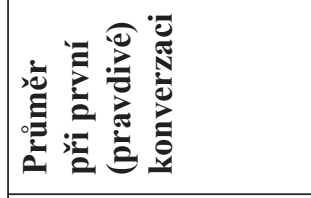 & ?? & $\stackrel{0}{\stackrel{1}{2}}$ & ? & $\vec{m}$ & $\begin{array}{l}0 \\
i \\
\end{array}$ & $\stackrel{?}{+}$ & $\frac{0}{6}$ \\
\hline 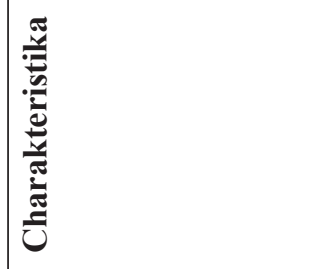 & 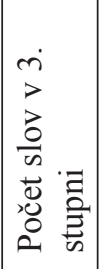 & 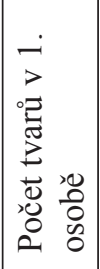 & 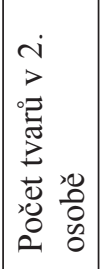 & 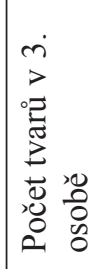 & 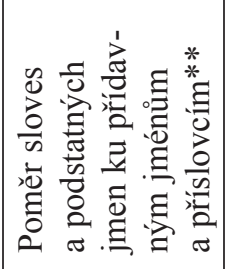 & 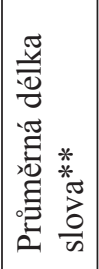 & 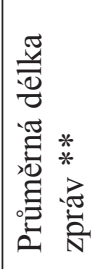 \\
\hline
\end{tabular}

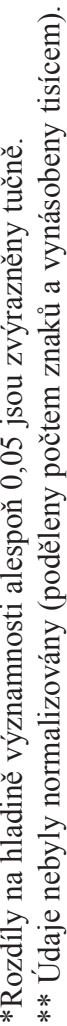


Položili jsme si rovněž otázku, zda se změna způsobu komunikace při lhaní liší u mužů a u žen. Analýzu jsme provedli zvlášt' pro muže a pro ženy, vzhledem k jejímu exploračnímu charakteru jsme stanovili hladinu statistické významnosti na 0,1 (pro t-test i jeho neparametrickou alternativu se ukázaly jako statisticky významné na této hladině stejné charakteristiky, v tabulkách uvádíme signifikanci t-testu). V Tabulkách 5 a 6 uvádíme pouze výsledky statisticky významné na hladině alespoň 0,1 a výsledky porovnání u charakteristik, u nichž se statisticky významný rozdíl ukázal při srovnání s výsledky celého souboru.

U mužů se z charakteristik, u nichž se ukázaly rozdíly mezi pravdivou a lživou komunikací pro celý soubor, neukázaly statisticky významné rozdíly u počtu otázek a průměrné délky zprávy. Naopak u pravdivé komunikace u mužů se vyskytlo oproti klamavé komunikaci více spojek a více slov ve třetím pádě, přičemž tyto rozdíly se u celého souboru neukázaly.

U žen se oproti rozdílům u celého zkoumaného souboru neukázal rozdíl u počtu slov ve druhém pádě, prvním stupni, počtu číslovek, př́islovcí a poměru podstatných jmen a sloves vůči př́slovcím a adjektivům. Naopak se ukázaly jako významné rozdíly u počtu slov ve druhém stupni, který byl vyšší u lživé komunikace, a počtu slov v první osobě, vyšším u komunikace pravdivé.

\section{Diskuse}

Charakteristiky jako počet příslovcí, číslovek nebo poměr počtu podstatných jmen a sloves vůči přídavným jménům a prŕíslovcím souvisí s mírou rozvitosti vět. Věta rozvitá větším počtem upřesňujících větných členů udává přesnější, tedy detailnější informaci. Námi zjištěný vyšší počet číslovek v pravdivé komunikaci tak odpovídá tendenci klamajících lidí uvádět méně detailní informace (De Paulo a kol. 2003). Námi zjištěný vyšší počet př́islovcí stejně jako zjištěný menší podíl podstatných jmen a sloves vůči přídavným jménům a př́slovcím (tedy rozvitost větných spojení) při lživé komunikaci je se zjištěním DePaulo a kol. (2003) týkajícím se komunikace tváŕí v tvář naopak v rozporu, stejně tak je v rozporu i se zjištěním Burgoon a Qin (2006), kde byl tento poměr u lživé komunikace tváří v tvář rovněž vyšší. U messengerové lživé komunikace však zjistili více detailů i Giordano a kol. (2007).

Zjištěný větší počet vět a větší počet částí vět při lživé komunikaci odpovídá zjištění Zhou a kol. (2004) při emailové komunikaci a Twitchella a kol. (2005) na chatu, ale je v rozporu se zjištěním Burgoon a Qin (2006) při komunikaci tváří v tvář. Tato zjištění ukazují na možnost, že při komunikaci přes internet se uplatňují jiné nápovědi pro detekci lhaní než při komunikaci tváří v tvář a že tyto nápovědi mohou mít opačný význam v závislosti na komunikačním médiu. Rovněž je možné, že se respondenti během messengerové komunikace dokáží lépe adaptovat na roli klamajícího (podobně jako ve Zhou a kol. 2003) a vymazat tak z komunikace rozdíly typické pro pravdivou či lživou komunikaci tváŕí v tvářr.

Vyšší průměrná délka zprávy zjištěná u pravdivé komunikace v podstatě odpovídá zjištění o větším počtu vět při lživé komunikaci - počet vět byl normován délkou komunikace, větší počet zde tedy znamená i menší průměrnou délku jedné věty.

Vyšší počet otázek při lživé komunikaci, zjištěný i Twitchellem a kol. (2005), možná odráží tendenci klamajících respondentů zbavit se nutnosti vymýšlet lživé údaje tím, že se druhého zeptají a přenechají aktivitu jemu. To odpovídá také zjištění Zhou a kol. (2004), že 
Václav Linkov, Pa vel Šmerk: Rozdíly mezi pravdivou a lživou online textovou komunikací

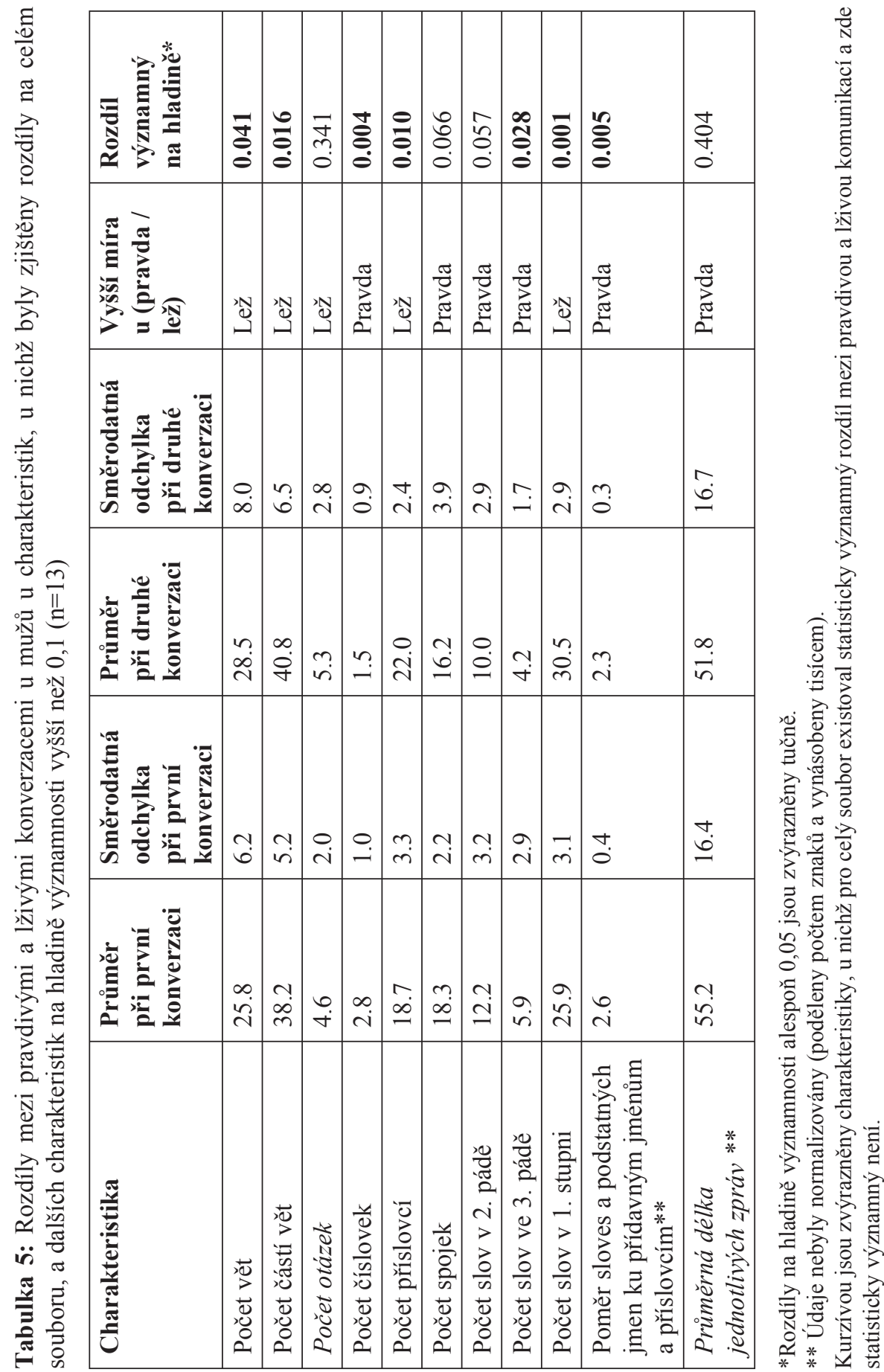




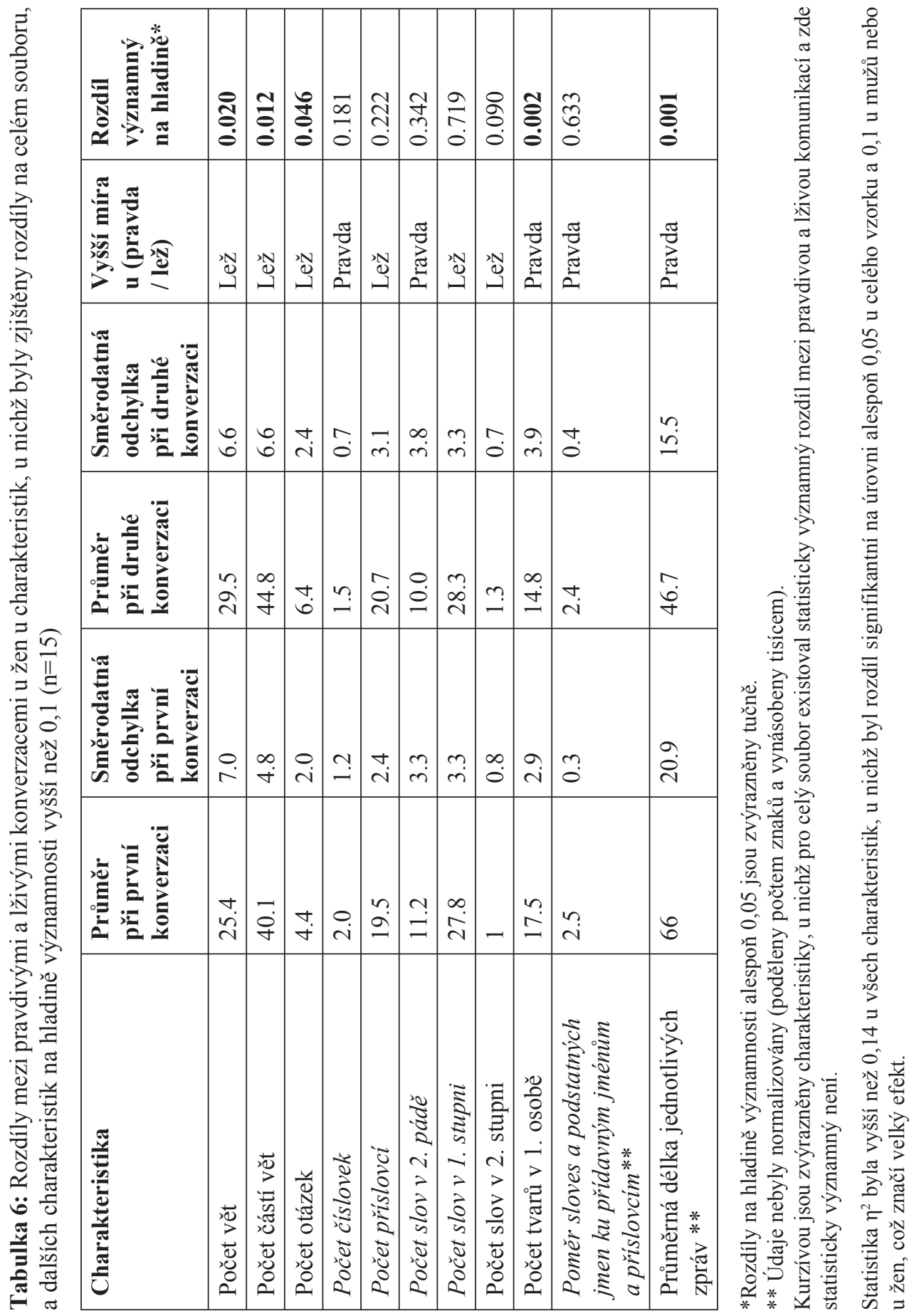


klamající se při komunikaci přes email postupně stávají dominantnějšími a více určují průběh konverzace.

Oproti našemu předpokladu se neukázal vztah mezi počtem dvoj/trojteček a lhaním. Vyšší počet slov ve druhém pádě při pravdivé a v prvním stupni při lživé komunikaci neumíme vysvětlit.

Srovnáme-li rozdíly nalezené mezi pravdivou a lživou komunikací u mužů a žen, ukazuje se zajímavý rozdíl: zatímco u mužů byly oproti ženám nalezeny statisticky významné rozdíly u charakteristik týkajících se použitého jazyka (počet slov ve druhém pádě, třetím pádě, prvním stupni, počtu číslovek, př́ślovcí, spojek a poměru podstatných jmen a sloves vůči př́íslovcím a adjektivům), u žen byly oproti mužům nalezeny rozdíly u charakteristik týkajících se strategie vedení rozhovoru (průměrná délka zprávy a počet otázek, navíc ještě počet slov ve druhém stupni a první osobě). Zdá se tedy, že u obou pohlaví se projevuje rozdílně odlišnost způsobu jejich psaní přes messenger v momentě, kdy dostanou za úkol lhát. Muži spíše používají jiný jazyk než tehdy, když nelhali, ženy spíš mění strategii komunikace, častěji se ptají, píši kratší vzkazy a komunikační aktivitu tak přenechávají svému partnerovi. Zdá se tedy, že automatická analýza lingvistických charakteristik má větší šanci na odhalení klamavé komunikace u mužů než u žen. Je ovšem třeba podotknout, že vzorek mužů i žen byl malý, toto zjištění je tedy třeba dále oveřrit.

Je otázkou, do jaké míry se nám podařilo dosáhnout toho, aby respondenti emitovali dostatek nápovědí pro snadnou detekci lhaní. $\mathrm{V}$ případě nalezení statisticky významných rozdílů to znamenalo, že pouze $60-70 \%$ respondentů vyprodukovalo danou charakteristiku ve větši míře v daném typu konverzace. Čas 40 minut mohl být dostatečně dlouhý na to, aby došlo k adaptaci (podobně jako u Zhoua a kol. 2003), desetiminutový čas na př́ípravu mohl být rovněž př́liš dlouhý a lepší prríprava mohla snížit počet nápovědí, snaha o navození motivace dotýkající se identity (De Paulo a kol. 2003; Bond, DePaulo 2006) se rovněž mohla minout účinkem, nutnost přemýšlet nad koncovkami pro opačné pohlaví nemusela vzbudit dostatečný stres nutící $\mathrm{k}$ chybám. Konečně nápovědi př́stupné lingvistické analýze nemusejí být těmito manipulacemi ovlivnitelné. Při kratši konverzaci, kratším čase na př́ípravu a jiném způsobu analýzy by tak mohly být nalezeny zřetelnější rozdíly mezi pravdivou a lživou messengerovou komunikací. Je rovněž otázkou, do jaké míry lze výsledky získané analýzou klamání v kontextu předstírání falešné identity aplikovat na lhaní obecně.

Další skutečností, která mohla ovlivnit náš výzkum, je, že utváření dojmu o důvěryhodnosti druhého a o jeho osobnosti se navzájem ovlivňují: Heinrich a Borkenau (1998) nechali své respondenty utvářet si názor na druhého a zjistili, že za dủvěryhodnějšího a konzistentnějšího mají lidé tendenci považovat člověka, o němž si myslí, že je více přívětivý. Pokud bychom tedy respondentům nezadali úkol vytvořit si názor na druhého, ale pouze konverzovat, mohla by se konverzace vyvíjet jinak.

Sledovaná konverzace mohla být ovlivněna i tím, že komunikační partneři respondentů byli v průměru o tři roky mladší. Komunikace s mladším partnerem majícím jiné zkušenosti a zájmy se může odvíjet jiným směrem, než by se odvíjela komunikace s partnerem stejně starým.

Je také třeba podotknout, že při stanovené pětiprocentní hladině významnosti u porovnání pro celý vzorek jsme se $\mathrm{s} 84 \%$ pravděpodobností $\mathrm{v}$ alespoň jednom př́padě dopustili 
chyby prvního typu a zjistili statisticky významný rozdíl, který ve skutečnosti neexistuje. U porovnání na desetiprocentní hladině významnosti zvlášt' pro ženy a muže je tato pravděpodobnost $98 \%$.

\section{Závěr}

Ukázali jsme, že při komunikaci přses messenger existují v češtině lingvistické kategorie, které se vyskytují v odlišné míře v pravdivé a lživé komunikaci. Vzhledem k použitému výzkumnému designu - tedy porovnávání pravdivé prezentace toho samého člověka s jeho lživou prezentací - ovšem nemůžeme př́ímo říci, že lze těchto kategorií použít pro rozlišení mezi pravdivou a lživou komunikací v reálné situaci, napřs. na chatu. Aby jich bylo možno použít, museli bychom mít $\mathrm{k}$ dispozici informaci o jejich průměrném výskytu při běžné konverzaci (vzhledem $\mathrm{k}$ délce vstupů) a zároveň informaci, o kolik se tento výskyt musí zvýšit či snížit, abychom dosáhli určité pravděpodobnosti (tř̌eba 80 \%), že jde o komunikaci lživou.

$\mathrm{V}$ našem výzkumu jsme rovněž sledovali jenom část nápovědí zjištěných v dřívějších článcích (Zhou a kol. 2004, DePaulo a kol. 2003, Vrij 2003, Burgoon, Qin 2006, Newman a kol. 2003). Výzkum zabývající se dalšími možnými nápověd’mi by mohl zjistit více rozdílů použitelných pro automatickou detekci lží na internetu.

Odlišné charakteristiky, u nichž byly nalezeny rozdíly mezi pravdivou a lživou komunikací u mužů a žen, nastolují otázku, zda automatickou detekci lží na internetu je vůbec možno provést s uspokojivou pravděpodobností úspěchu, když neznáme pohlaví pisatele. Zdá se tedy, že výzkum zaměřený tímto směrem by měl brát pohlaví klamajících v úvahu ve větší míre, než bylo obvyklé ve většině námi citovaných studií.

Náš článek je tak pouze prvním př́spěvkem, který by mohl vést k vytvoření nástroje pro automatickou detekci lhaní na internetu $\mathrm{v}$ češtině. Navazující výzkum by měl vzít $\mathrm{v}$ úvahu námi nalezené kategorie a zjistit jejich průměrný výskyt $\mathrm{v}$ běžné konverzaci stažené napřs. $\mathrm{z}$ chatů. Na základě takových údajů by mohly být vytvořeny rozlišovací funkce, které by poté bylo třeba otestovat $\mathrm{v}$ experimentálních podmínkách a u nichž by bylo třeba ověřit, zda jsou schopny s dostatečnou přesností rozlišit mezi pravdivou a lživou komunikací. V př́ípadě nalezení vhodné rozlišovací funkce ji pak bude možno použít při detekci falešných sebeprezentací tam, kde je takové detekce potřeba.

\section{Poděkování}

Za pomoc při administraci děkujeme Davidu Šmahelovi, Lubici Kečkešové a Haně Macháčkové. Za kritické připomínky děkujeme Martině Hřebíčkové, Davidu Šmahelovi, Lence Golecké, Zbyňku Vybíralovi a účastníkům pilotního výzkumu. Za půjčení počítačových učeben děkujeme Celouniverzitní počítačové studovně MU a Centru informačních a komunikačních technologií FSS MU. Všem respondentům děkujeme za jejich čas a ochotu. 


\section{Literatura}

ANDERSON, D. Eric ; DePAULO, Bella M. ; ANSFIELD, Matthew E. ; TICKLE, Jennifer J. ; GREEN, Emily. Beliefs about cues to deception: Mindless stereotypes or untapped wisdom? Journal of Nonverbal Behavior, 1999, roč. 23, č. 1, s. 67 - 89. ISSN 1573-3653.

CASPI, Avner ; GORSKY, Paul. Online Deception: Prevalence, Motivation, and Emotion. CyberPsychology \& Behavior, 2006, roč. 9, č. 1, s. 54 - 59. ISSN 1094-9313.

BOND, Charles F. Jr. ; DePAULO, Bella M. Accuracy of Deception Judgments. Personality and Social Psychology Review, 2006, roč. 10, č. 3, s. 214 -234. ISSN 1532-7957.

BOND, Charles F. Jr. ; DePAULO, Bella M. Individual Differences in Judging Deception: Accuracy and Bias. Psychological Bulletin, 2008, roč. 134, č. 4, s. 477 - 492. ISSN 0033-2909.

BOND, Gary D. Deception Detection Expertise. Law and Human Behavior, 2008, roč. 32, č. 4, s. 339 - 351. ISSN 1573-661X.

BURGOON, Judee K. ; QIN, Tiantian. The Dynamic Nature of Deceptive Verbal Communication. Journal of Language and Social Psychology, 2006, roč. 25, č. 1, s. 76 - 96. ISSN 1552-6526.

DePAULO, Bella M. ; LANIER, Keith ; DAVIS, Tracy. Detecting the Deceit of the Motivated Liar. Journal of Personality and Social Psychology, 1983, roč. 45, č. 5, s. $1096-1103$. ISSN 0022-3514.

DePAUL, Bella M. ; LINDSAY, James J. ; MALONE, Brian E. ; MUHLENBRUCK, Laura ; CHARLTON, Kelly ; COOPER, Harris. Cues to Deception. Psychological Bulletin, 2003, roč. 129, č. 1, s. 74 - 118. ISSN 0033-2909.

EKMAN, Paul ; O’SULLIVAN, Maureen ; FRANK, Mark G. A Few Can Catch a Liar. Psychological Science, 1999, roč. 10, č. 3, s. 263 - 266. ISSN 1467-9280.

FEELEY, Thomas Hugh ; YOUNG, Melissa J. Self-Reported Cues About Deceptive and Truthful Communication: The Effects of Cognitive Capacity and Communicator Veracity. Communication Quarterly, 2000, roč. 48, č. 2, s. 101 - 119. ISSN 1746-4102.

FORD, Elizabeth B. Lie detection: Historical, neuropsychiatric and legal dimensions. International Journal of Law and Psychiatry, 2006, roč. 29, č. 3, s. 159 - 177. ISSN 0160-2527.

FORGAS, Joseph P. ; EAST, Rebekah. On being happy and gullible: Mood effects on skepticism and the detection of deception. Journal of Experimental Social Psychology, 2008, roč. 44, č. 5, s. $1362-1367$. ISSN 0022-1031.

FORREST, James A. ; FELDMAN, Robert S. Detecting Deception and Judge's Involvement: Lower Task Involvement Leads to Better Lie Detection. Personality and Social Psychology Bulletin, 2000, roč. 26 , č. 1 , s. $118-125$. ISSN 1552-7433.

GEORGE, Joey F. ; BIROS, David P. ; BURGOON, Judee K. ; NUNAMAKER, Jay F. Jr. Training Professionals to Detect Deception. In CHEN, H., NUNAMAKER, J.F., BURGOON, J.K., THOMPSON, P., WHINSTON, A.B., LIN, C., XU, J., CANDAN, K.S., LIN, P., BROWN, D.E. Intelligence and Security Informatics 2003. 1. vyd. Berlin : Springer, 2003, s. $366-370$. ISBN 978-3-540-40189-6.

GIORDANO, Gabriel A. ; STONER, Jason S. ; BROUER, Robyn L. ; GEORGE, Joey F. The Influences of Deception and Computer-Mediation on Dyadic Negotiations. Journal of Computer-Mediated Communication, 2007, roč. 12, č. 2, s. 362 - 383. ISSN 1083-6101.

HANCOCK, Jeffrey T. ; THOM-SANTELLI, Jennifer ; RITCHIE, Thompson. Deception and Design: The Impact of Communication Technology on Lying Behavior. In DYKSTRA-ERICKSON, E. Proceedings of the SIGCHI conference on Human factors in computing systems 2004. 1. vyd. New York : ACM Press, 2004, s. 129 - 134. ISBN 1-58113-702-8.

HARTWIG, Maria ; GRANHAG, Pär Anders ; STRÖMWALL, Leif A. ; KRONKVIST, Ola. Strategic Use of Evidence During Police Interviews: When Training to Detect Deception Works. Law and Human Behavior, 2006, roč. 30, č. 5, s. 603 - 619. ISSN 1573-661X. 
HEINRICH, Christina U. ; BORKENAU, Peter. Deception and Deception Detection: The Role of Cross-Modal Incosistency. Journal of Personality, 1998, roč. 66, č. 5, s. 687 - 712. ISSN 1467-6494.

HYMAN, Ray. The Psychology of Deception. Annual Review of Psychology, 1989, roč. 40, č. 1, S. 133 - 154. ISSN 0066-4308.

KASSIN, Saul M. ; FONG, Christina T. "I'm Innocent!": Effects of Training on Judgments of Truth and Deception in the Interrogation Room. Law and Human Behavior, 1999, roč. 23, č. 5, s. 499 - 516. ISSN 1573-661X.

KOUBALÍKOVÁ, Sylvie ; ŠMAHEL, David. Fenomén lhaní v prostředí Internetu. Československá Psychologie, 2008, roč. 52, č. 3, s. 289 - 301. ISSN 0009-062X.

MANN, Samantha ; VRIJ, Aldert ; BULL, Ray. Detecting True Lies: Police Officers' Ability to Detect Suspects' Lies. Journal of Applied Psychology, 2004, roč. 89, č. 1, s. 137 - 149. ISSN 0021-9010.

MEISSNER, Christian A. ; KASSIN, Saul M. „He's Guilty!”: Inestigator Bias in Judgments of Truth and Deception. Law and Human Behavior, 2002, roč. 26, č.5, s. 469 - 479. ISSN 1573-661X.

NEWMAN, Matthew L. ; PENNEBAKER, James W. ; BERRY, Diane S. ; RICHARDS, Jane M. Lying Words: Predicting Deception from Linguistic Styles. Personality and Social Psychology Bulletin, 2003, roč. 29, č. 5, s. $665-675$. ISSN 1552-7433.

PORTER, Stephen ; CAMPBELL, Mary Ann ; STAPLETON, Jennifer ; BIRT, Angela R. The Influence of Judge, Target, and Stimulus Characteristics on the Accuracy of Detecting Deceit. Canadian Journal of Behavioural Science, 2002, roč. 34, č. 3, s. 172 - 185. ISSN 0008-400X.

RIGGIO, Ronald E. ; FRIEDMAN, Howard S. Individual Differences and Cues to Deception. Journal of Personality and Social Psychology, 1983, roč. 45, č. 4, s. 899 - 915. ISSN 0022-3514.

SEDLÁČEK, Radek ; SMRŽ, Pavel. A New Czech Morphological Analyser ajka. In Proceedings of Text, Speech and Dialog Conference, TSD 2001, LNAI 2166, Springer Verlag, Berlin 2001. ISBN 3-540-42557-8.

STRÖMWALL, Leif A. ; GRANHAG, Pär Anders. Affecting the Perception of Verbal Cues to Deception. Applied Cognitive Psychology, 2003, roč. 17, č. 1, s. 35 - 49. ISSN 0888-4080.

ŠMERK, Pavel. K morfologické desambiguaci češtiny. Brno : Masarykova univerzita, 2008. [Rigorózní práce].

TWITCHELL, Douglas P. ; NUNAMAKER, Jay F. Jr. ; BURGOON, Judee K. Using Speech Act Profiling for Deception Detection. . In CHEN, H., NUNAMAKER, J.F., BURGOON, J.K., WIJESEKERA, D., XU, J., GOLDBERG, M., FARKAS, C., ZHONG, Y., YENER, B., MAGDON-ISMAIL, M. Intelligence and Security Informatics 2004. 1. vyd. Berlin : Springer, 2004. s. $403-410$. ISBN 978-3-540-22125-8.

TWITCHELL, Doug, P. ; FORSGREN, Nicole ; WIERS, Karl ; BURGOON, Judee K. ; NUNAMAKER, Jay F. Jr. Detecting Deception in Synchronous Computer-Mediated Communication Using Speech Act Profiling. In CHEN, H., WANG, F., DANTU, R., BURGOON, J.K., THOMBORSON, C., QIN, J., SHETH, A., KOPPEL, M., CHOUDHARY, A., QIAO, H. Intelligence and Security Informatics 2005. 1. vyd. Berlin : Springer, 2005, s. 471 - 478. ISBN 978-3-540-25999-2.

VRIJ, Aldert. Detecting Lies and Deceit. The Psychology of Lying and the Implications for Professional Practice. 1. vyd. Chichester : John Wiley \& Sons, Ltd., 2000. 254 s. ISBN 0-471-85316-X..

VRIJ, Aldert ; MANN, Samantha. Detecting Deception: Benefit of Looking at a Combination of Behavioral, Auditory and Speech Content Related Cues in a Systematic Manner. Group Decision and Negotiation, 2004, roč. 13, č. 1, s. 61 - 79. ISSN 1572-9907.

ZHOU, Lina ; BURGOON, Judee K. ; TWITCHELL, Doug P. A Longitudinal Analysis of Language Behavior of Deception in E-mail. In CHEN, H., NUNAMAKER, J.F., BURGOON, J.K., THOMPSON, P., WHINSTON, A.B., LIN, C., XU, J., CANDAN, K.S., LIN, P. ; BROWN, D.E. In- 
telligence and Security Informatics 2003. 1. vyd. Berlin : Springer, 2003, s. 102 - 110. ISBN 978-3-540-40189-6.

ZHOU, Lina ; BURGOON, Judee K. ; NUNAMAKER, Jay F. Jr. ; TWITCHELL, Doug P. Automatic Linguistic-Based Cues for Detecting Deception in Text-Based Asynchronous ComputerMediated Communication. Group Decision and Negotiation, 2004, roč. 13, č. 1, s. 81 - 106. ISSN $1572-9907$.

ZHOU, Lina ; BURGOON, Judee K. ; ZHANG, Dongsong ; NUNAMAKER, Jay F. Jr. Language dominance in interpersonal deception in computer-mediated communication. Computers in Human Behavior, 2004, roč. 20, č. 3, s. 381 - 402. ISSN 0747-5632.

\section{Autoři}

Václav Linkov absolvoval magisterská studia diskrétní matematiky na PřF MU a psychologie na FSS MU. Několik let pracoval jako programátor informačních systémů na bázi Microsoft Dynamics-NAV, působil také jako lektor matematiky na MZLU. V současné době studuje doktorský studijní program sociální psychologie na FSS MU.

Kontakt: linkov@email.cz

Pavel Šmerk absolvoval obor Informatika na FI MU, v současnosti je doktorským studentem tamtéž a bakalářským studentem kombinace český jazyk a obecná jazykověda na FF MU. Je zaměstnán jako odborný pracovník Centra zpracování přirozeného jazyka a jako programátor Centra výpočetní techniky, obojí na FI MU. Vytvořil programovou část Internetové jazykové přiručky oceněné Medailí MŠMT 1. stupně.

Kontakt: smerk@mail.muni.cz 